\title{
Oyster sex determination is influenced by temperature - First clues in spat during first gonadic differentiation and gametogenesis
}

\author{
Christelle Santerre ${ }^{a, b, c}$, Pascal Sourdaine ${ }^{a, b, c}$, Nicolas Marc $^{d}$, Christian Mingant $^{d}$, René Robert ${ }^{d}$, \\ Anne-Sophie Martinez ${ }^{a, b, c, *}$
}

\author{
${ }^{a}$ Normandie Univ, France \\ b UCBN, BIOMEA, F-14032 Caen, France \\ ${ }^{c}$ CNRS-INEE, FRE 3484, F-14032 Caen, France \\ d Laboratoire de Physiologie des Invertébrés IFREMER Brest, Station expérimentale d'Argenton, F-29840 \\ Argenton Landunvez, France \\ *: Corresponding author : Anne-Sophie Martinez, tel.: + 33231565164 ; fax: + 33231565346 ;
email address : $\underline{\text { anne-sophie.martinez@unicaen.fr }}$
}

\begin{abstract}
:
The sex-determining system of Crassostrea gigas is still poorly known, especially regarding the potential influence of temperature. In order to address this question, mRNA expressions of actors of the molecular cascade (Cg-DMl, Cg-SoxE, Cg- $\beta$-catenin, Cg-Foxl2/Cg-Foxl2os) and of Oyvlg, a germ cell marker, were investigated by real-time PCR in spat grown at different temperatures $(18,22,25$ and $28{ }^{\circ} \mathrm{C}$ ). In parallel, gonadic differentiation, gametogenesis and sex ratios were assessed by histology at each of these temperatures. Whatever the temperature, Cg-DMl, $\mathrm{Cg}$-SoxE, Cg- $\beta$-catenin and Oyvlg expressions peaked at the same developmental stage, always after $\mathrm{Cg}-\mathrm{Foxl} / \mathrm{Cg}$-Foxl2os (around 40-44 dpf for spat grown at $18{ }^{\circ} \mathrm{C}$ ). Temperatures increased the kinetics of first gonadic differentiation and gametogenesis. At $25^{\circ} \mathrm{C}$ a significant switch occurred in sex ratio towards males and in the balance of expression between male and female genes, in favor of males. A slight gametogenesis disturbance was also observed. These results strengthen the hypotheses about the sex-determining time window and molecular cascade governing the development of $C$. gigas, with notably the involvement of $\mathrm{Cg}-\mathrm{Foxl} / \mathrm{Cg}$-Foxl2os in the very early steps. They also suggest an influence of temperature on the oyster's sex determination which, associated to genetic control, would induce a mixed sex determination system (GSD + TSD).
\end{abstract}

Keywords: Oyster spat ; Temperature ; Sex ratio ; TSD ; Sex determination pathway 


\section{Introduction}

The question of diversity of sex determination mechanisms is still currently puzzling for many researchers. Indeed, among vertebrates, mammals and birds have genetic sex determination (GSD), some reptilians and fish have environmentally-governed sex determination (ESD) and others including many fish and amphibians have a mixture of GSD and ESD (Valenzuela et al., 2003; Wedekind and Stelkens, 2010). The main factors involved in ESD mechanisms are food availability, population density and temperature (we then talk about TSD, 'Temperaturedependant Sex Determination') (Pradeep et al., 2012). TSD is widespread among animal taxa, from invertebrates such as rotifers, nematods, crustaceans, mollusks and insects to vertebrate species like reptilians and fish (Korpelainen, 1990). In species with TSD, temperature only affects sex determination (during the development in gonochoric species and at each sex reversion in hermaphrodites) during a critical time window called thermo-sensitive period (TSP) (Manolakou et al., 2006). Such species could be regarded as indicators of global warming; by significantly affecting ecosystems, rising temperatures could alter natural sex ratios and over time potentially lead to local extinctions (Janzen, 1994).

In the Pacific oyster Crassostrea gigas, an irregular successive protandric hermaphrodite, still poorly known sex determination is thought to be controlled by a major gene and influenced by the environment (Hedrick and Hedgecock, 2010; Guo et al., 2012). Downstream secondary actors of the molecular cascade of sex determination/gonadic differentiation have been characterized in adults, but also during development (male orthologs Cg-DMl and Cg-SoxE - female orthologs Cg-Fox12 and Cg- $\beta$-catenin - a natural antisense transcript Cg-Fox12os) (Naimi et al., 2009a; b; Santerre et al., 2012 and unpublished data). This cascade shows a balance of gene expressions between male and female orthologs according to the future sex of the animal. The gene expression profiles suggest a sex determination time window in adults at the transition between the end of a cycle and the beginning of the next, and in $45-60 \mathrm{dpf}$ spat grown at $18^{\circ} \mathrm{C}$ and fed $\mathrm{ad}$ libitum. In adult oysters, an influence of temperature on sex determination has been suspected for many years. Indeed, as early as 1936 , Coe mentioned in $C$. virginica a female-biased sex ratio at high temperatures (Coe, 1936). In C. gigas, a one-year conditioning at low temperatures $\left(8^{\circ} \mathrm{C}\right)$ induced a male-biased sex ratio (Fabioux et al., 2005). However, in contrast, nothing is known on 
the effect of temperature on sex determination in oyster's developmental stages, although young specimens may be more sensitive to environmental changes than adults. Moreover, very little is known about the first oyster's gonadic differentiation and gametogenesis. Concerning spat, some quite old studies (Galtsoff, 1964; Tardy, 1970; Lubet et al., 1976) indicate that gonads originate from one or two groups of primordial germ cells (PGCs) located on the ventral side of the pericardium, in the vicinity of the visceral ganglion, and which differentiate into germinal stem cells (GSCs) before the first reproductive cycle. According to Naimi et al. (2009b), undifferentiated germ cells would already be present in the gonadal tubules in 90-120 dpf spat grown at $18^{\circ} \mathrm{C}$.

In this context, the objective of our work was to highlight the effect four different temperature levels $\left(18,22,25\right.$ and $\left.28^{\circ} \mathrm{C}\right)$ may have on spat sex determination, by studying sex ratios, expressions of putative sex-determining genes (Cg-DM1, Cg-Fox12/Cg-Fox12os, Cg-SoxE and Cg- $\beta$-catenin) and Oyvlg, a germ cell marker. The kinetics of first gonadic differentiation and gametogenesis were also assessed in parallel.

\section{Material and methods}

\subsection{Experimental animals and conditioning}

In order to limit their genetic diversity, animals originated from one fertilisation of gametes produced by genitors of the same family. Fertilisation, larval development, settlement and metamorphosis occurred at the Ifremer hatchery in Argenton (Brittany, France) in spring 2011, following the experimental process previously described by Rico-Villa et al. (2006). Twenty eight dpf-old spat (shell length between 0.5 and $0.7 \mathrm{~mm}$ ) were then transferred to vertical $500 \mathrm{~mL}$ cylindrico-conical tubes in a flow-through system (FTS) (Rico-Villa et al., 2008) and maintained at 4 different temperature levels, $18,22,25$ and $28^{\circ} \mathrm{C}$. Food was delivered to maintain in each tube an optimal and constant concentration $\left(1500 \mu \mathrm{m}^{3} \cdot \mu \mathrm{L}^{-1}\right)$ of $50 / 50(\mathrm{v} / \mathrm{v}) \mathrm{mix}$ of Isochrysis affinis galbana $(\mathrm{T})\left(18750\right.$ cells. $\left.\mathrm{mL}^{-1}\right)$ /Chaetoceros calcitrans forma pumilum $(\mathrm{Cg})(9400$ cells. $\left.\mathrm{mL}^{-1}\right)$. The growth rates observed were similar to the optimal growth rates obtained experimentally for spat grown in FTS (R. Robert, personal communication) and from a DEB model for larvae (Rico-Villa et al., 2010). Sampling was done on a periodic basis, based on 
temperature and development kinetics: daily at $28^{\circ} \mathrm{C}$ for 11 days, each second, third and fourth day at 25,22 and $18^{\circ} \mathrm{C}$, respectively for a duration of 18,24 and 28 days. Samples were prepared for RNA extractions and histology. In order to determine spat sex ratios by histology, a last sampling was performed after 21 days of conditioning for animals kept at 25 and $28^{\circ} \mathrm{C}$, and after a 28 -day and a 58 -day conditioning period at $22^{\circ} \mathrm{C}$ and $18^{\circ} \mathrm{C}$ respectively. The spat were then respectively 49, 56 and $86 \mathrm{dpf}$ old.

\subsection{Total RNA extractions}

Total RNAs were extracted from 6 pools of 10 spat before the start of the conditioning process and at each sampling time, for each temperature, using Tri-Reagent (Sigma, Saint Quentin Fallavier, France), following the manufacturer's instructions.

\subsection{Real time RT-PCR}

After DNAse I RQ1 (Promega, Charbonnières, France) treatment, 500 ng of total RNA samples (from 6 pools of 10 individuals) were reverse-transcribed using $200 \mathrm{U}$ of M-MLV Reverse Transcriptase (Promega) for $90 \mathrm{~min}$ at $37^{\circ} \mathrm{C}$, and with oligod $(\mathrm{T})_{15}$ primer (Promega) or FoxAS2 (5' CCGCCGGATAGTCGTTAAG 3') and FoxS4 (5' AGTATTCGCCACAATTTGAGCTTAAAT 3') for reverse transcriptions of $\mathrm{Cg}$-Foxl2 and $\mathrm{Cg}$-Fox12os, respectively. PCR experiments were cycled $45 \mathrm{x}\left(15 \mathrm{~s} / 95^{\circ} \mathrm{C}, 45 \mathrm{~s} / 60^{\circ} \mathrm{C}\right)$ after $15 \mathrm{~min} / 95^{\circ} \mathrm{C}$ in a final volume of $15 \mu \mathrm{L}$, using the CFX96 Touch ${ }^{\mathrm{TM}}$ Real-Time PCR Detection System (BioRad, Marnes-La-Coquette, France) with 5 ng template DNA, $7.5 \mu \mathrm{L}$ of GoTaq ${ }^{\circledR}$ qPCR Master Mix (Promega) and $300 \mathrm{nM}$ of specific forward and reverse primers. Reactions with RNAs not reverse-transcribed were used as negative controls. Accurate amplifications of target amplicons were assessed by plotting melting curves, and PCR amplification efficiency $\left(E=10^{(-1 / \text { slope })}\right)$ was determined for each primer pair by linear regression analysis of a dilution series over several samples. DNA amplifications were performed using specific pairs of primers listed in Table 1. The relative mRNA levels were normalized to EF1 $\alpha$ transcripts through the following formula, $\mathrm{N}=10 \times 2^{\text {(Ct EFl } \alpha \text { - } \mathrm{Ct} C g \text {-gene) }}$.

\subsection{Histology}

Spat were fixed in Davidson's fixative for $24 \mathrm{~h}$, after a hole was made in their shells to improve the soaking of soft tissues. The animals were then unshelled in $70 \%$ ethanol under a binocular 
microscope, dehydrated and embedded in paraffin. A series of $5 \mu \mathrm{m}$-thick sections were cut and stained with a Prenant-Gabe trichrome following a classical protocol (Gabe, 1968). Slides were examined and pictures taken with an Eclipse 80i microscope coupled to a DXM1200-C camera (Nikon, Champigny sur Marne, France). Sex ratios were assessed in relation to temperature on 27 to 50 individuals ( 4 slides/spat). The effect of temperature on the kinetics of first gonadic differentiation and gametogenesis was also determined in specimens of the same age, after observation of 4 slides of 5 animals, at the most frequent stage of gonadic differentiation and gametogenesis observed in one temperature condition. Criteria used to assess progress of gonadic differentiation and gametogenesis are summarized in Table 2. They include the number of collecting ducts and gonadal tubules, the number of germ cells and their relative proportions.

\subsection{Statistical analysis}

To test for significant differences of temperature effects on sex ratios and gene expression levels (moments of peaks and differences of expression between two genes), several statistical methods were used. The effect of four temperature levels (between 18 and $28^{\circ} \mathrm{C}$ ) on sex ratios was evaluated by a $\chi^{2}$ test on 27 to 50 individuals (independent replicates). The effect of temperature on gene expression levels was assessed on 6 pools of 10 spat/age (dpf)/temperature by using a 2tailed Mann-Whitney U-test. Levels were accepted as significant at $\mathrm{p}<0.05$. Statistical analyses were conducted using SigmaStat software.

\section{Results}

\subsection{Effect of temperature on the kinetics of first gonadic differentiation and gametogenesis}

Table 3 illustrates, at each of the four temperatures tested, the kinetics of first gonadic differentiation and gametogenesis in spat of the same age, arbitrarily set at $49 \mathrm{dpf}$. The average length of unshelled animals varies according to temperature, from $3.69 \mathrm{~mm}$ at $18^{\circ} \mathrm{C}$ to $9.26 \mathrm{~mm}$ at $28^{\circ} \mathrm{C}$. Criteria used to assess the kinetics of gonadic differentiation are the number of collecting ducts and the number of gonadal tubules, and for gametogenesis the number and proportions of the type of germ cells observed.

At 18 and $22^{\circ} \mathrm{C}$, gonadic areas only exhibit few collecting ducts with few round germ cells which may be either primordial or undifferentiated germ cells. The number of collecting ducts exhibits a 
3 to 5 -fold increase as the temperature drops to $22^{\circ} \mathrm{C}$. From 25 to $28^{\circ} \mathrm{C}$, almost all the animals can be sexed: they exhibit gonadal tubules which get more abundant as the temperature increases. Collecting ducts are also more frequent than in specimens exposed to lower temperatures. In both cases they are filled with differentiated germ cells, at $25^{\circ} \mathrm{C}$, in majority oogonia in females (results not shown) and spermatogonia and spermatocytes in males. Some of the latter also sometimes exhibit spermatids (results not shown). At $28^{\circ} \mathrm{C}$, all types of germ cells are observed, and tubules and ducts are filled with a majority of vitellogenic oocytes in females (results not shown) and spermatids in males. Above $25^{\circ} \mathrm{C}$, some animals exhibit a disturbed, although complete, gametogenesis with very few differentiated germ cells (results not shown).

\subsection{Effect of temperature on sex ratio}

For each temperature, sex ratio was assessed on spat which could be sexed (Fig. 1). Few undetermined individuals were also observed (results not shown), although they were not taken into account for analysis. This determination was based on histological observations of the gonadic area. In adults this is a diffuse organ made of numerous tubules (including collecting ducts), site of gametogenesis, embedded in connective storage tissue. Histological pictures of Figure 1 aim to illustrate some random gametogenesis processes but not any specified degree of maturation since animals are not the same age. The histogram of Figure 1 shows a change in spat sex ratios according to temperature (from 18 to $28^{\circ} \mathrm{C}$ ) but significant effects are statistically observed only between 18 and $28^{\circ}\left(\chi^{2}\right.$ test, $p<0.05$, the star indicates significant differences of expression between the two temperatures). At $18^{\circ} \mathrm{C}$, sex ratio is biased towards females (1.4:1). The gonadic area is only made of extended collecting ducts, mainly filled with spermatogonia and spermatocytes in males (data not shown), and some oogonia in females (Fig. 1 A). At $22^{\circ} \mathrm{C}$, sex ratio is still biased towards females, although to a lesser extent (1.2:1). Males for instance (Fig. 1B), exhibit many spermatogonia and spermatocytes. Between 22 and $25^{\circ} \mathrm{C}$, a switch in sex ratio seems to occur and at $25^{\circ} \mathrm{C}$, it is then slightly in favor of males $(1: 1.1)$. These, then exhibit spermatogonia, spermatocytes, few spermatids and even spermatozoa in some individuals, while female tubules are filled with oogonia and pre-vitellogenic oocytes (results not shown). At this temperature, some simultaneous hermaphrodites $(2.7 \%)$ are also present. At $28^{\circ} \mathrm{C}$, a strong malebiased sex ratio is observed (1:2). Numerous vitellogenicoocytes and spermatozoa are then 
observed respectively in females (Fig. 1D) and in males (results not shown). Some mature individuals with only spermatozoa can also be observed (results not shown). At this temperature, simultaneous hermaphrodites are more frequent compared to $25^{\circ} \mathrm{C}$ and always exhibit female germ cells more peripheral in the gonadal tubules than male germ cells (Fig 1C).

\subsection{Effects of temperature on the expression of candidate sex determination genes} Messenger RNA expression profiles in spat at the four different temperature levels have been assessed by real-time PCR for the five sex determination candidate genes (male orthologs CgDMl and Cg-SoxE - female orthologs Cg-Foxl2 and Cg- $\beta$-catenin - the natural antisense transcript Cg-Fox12os) and for Oyvlg, the germ cell marker. Two-tailed Mann-Whitney U-tests $(\mathrm{n} 1=\mathrm{n} 2=6)$ carried out on the resulting PCR values show some specific significant effects of temperature on gene expression levels.

At $18^{\circ} \mathrm{C}$ (Fig. $2 \mathrm{~A}-\mathrm{C}$ ), Oyvlg, Cg-SoxE, $\mathrm{Cg}-\mathrm{DMl}$ and $\mathrm{Cg}-\beta$-catenin present significant peaks of expression in 44-dpf spat $(\mathrm{U} \leq 5, \mathrm{p}<0.05$ two-tailed; for instance for $\mathrm{Cg}-\mathrm{SoxE}, \mathrm{U}=2$ when comparing stage 36 with $44 \mathrm{dpf}$; not illustrated by letters on the graphs), 16 days after the beginning spat exposition to a different temperature level (Fig. 2A). The gonad is still not visible, as illustrated by histological picture (Fig. 2B). The area where the gonad is expected only shows the kidney and digestive gland. Although high individual variability is observed and differences are therefore not statistically significant, the expression profiles show a general tendency with $\mathrm{Cg}-\beta$-catenin more expressed than male orthologs $\mathrm{Cg}-\mathrm{DMl}$ and $\mathrm{Cg}-\mathrm{SoxE}(\mathrm{U}=8$ for both gene comparisons with $\mathrm{Cg}-\beta$-catenin). $\mathrm{Cg}$-Foxl2 and $\mathrm{Cg}$-Fox12os expressions (Fig. 2C) show a significant peak earlier than other genes in 40-dpf spat $(U \leq 5, p<0.05$ two-tailed; for instance for Cg-Foxl2 $\mathrm{U}=5$ and 0 respectively for comparisons with 36 and $44 \mathrm{dpf}$; not illustrated by letters on the graphs). The first factor exhibits significantly higher levels compared to the other ( $U=3$, $\mathrm{p}<0.05$ two-tailed; stars indicate significant differences of expression between the two genes).

At $22^{\circ} \mathrm{C}$ (Fig. 3A-C), Oyvlg, Cg-SoxE, Cg-DMl and Cg- $\beta$-catenin expressions significantly peak earlier than at $18^{\circ} \mathrm{C}$ in spat aged $37 \mathrm{dpf}, 9$ days after the beginning of the experiment $(\mathrm{U} \leq 5$, $\mathrm{p}<0.05$ two-tailed; for instance for $\mathrm{Cg}-\mathrm{SoxE}, \mathrm{U}=2$ for the comparison with 40-dpf spat; not illustrated by letters on the graphs) (Fig. 3A). Again, gonads are not visible at this developmental stage (Fig. 3B). Cg- $\beta$-catenin expression is significantly higher than male orthologs $\mathrm{Cg}$-SoxE and Cg-DMl expressions ( $\mathrm{U}=5$ and 4 respectively for both gene comparisons with $\mathrm{Cg}-\beta$-catenin, 
$\mathrm{p}<0.05$ two-tailed; stars indicate significant differences of expression between two genes). Again, Cg-Foxl2 and Cg-Foxl2os show significant peaks of expression before other genes, in 31-34-dpf spat $(\mathrm{U} \leq 5, \mathrm{p}<0.05$ two-tailed; for instance for $\mathrm{Cg}$-Foxl2 $\mathrm{U}=0$ for comparison with 28 and 37-dpf spat; not illustrated by letters on the graphs) (Fig. 3C). In contrast with $18^{\circ} \mathrm{C}$ data, neither expression is significantly differentiated $(\mathrm{U}=10)$, although $\mathrm{Cg}$-Foxl2 expression still tends to be higher than that of its NAT (Fig. 3C). Some small significant peaks of expression are also observed, especially for $\mathrm{Cg}-\mathrm{SoxE}$ and $\mathrm{Cg}-\beta$-catenin, but also for $\mathrm{Cg}$-Foxl2 and $\mathrm{Cg}$-Foxl2os (Fig. $3 \mathrm{~A}$ and $\mathrm{C})$.

At $25^{\circ} \mathrm{C}$ (Fig. 4A-C), the most significant peaks of expressions of Oyvlg, Cg-SoxE, Cg-DMl and Cg- $\beta$-catenin appear earlier compared to data obtained for the lower temperature experiments in 34-dpf spat ( $U \leq 5, p<0.05$ two-tailed; for instance for Cg-SoxE $U=4$ for comparison between 30 and 34-dpf spat; not illustrated by letters on the graphs) (Fig. 4A), 6 days after the beginning of the test, when the gonad is absent (Fig. 4B). In contrast with lower temperatures, there is now a general trend towards higher male gene expressions ( $\mathrm{Cg}-\mathrm{DMl}$ and $\mathrm{Cg}$-Sox E) than female $(\mathrm{Cg}-\beta$ catenin), but expression levels are not significantly different (for instance $U=16$ for comparison of $\mathrm{Cg}$ - $\beta$-catenin with $\mathrm{Cg}$-DMl). $\mathrm{Cg}$-Foxl2 and $\mathrm{Cg}$-Foxl2os expressions significantly increase earlier in spat aged $32 \mathrm{dpf}$ (for instance for $\mathrm{Cg}$-Foxl2os, $\mathrm{U}=1$ when comparing stages 32 and 34 dpf; $\mathrm{p}<0.05$ two-tailed; not illustrated by letters on the graphs), without being significantly different ( $\mathrm{U}=17)$ (Fig. 4C). Some small non-significant peaks of expression are also observed for Cg-DMl, Cg-SoxE, Oyvlg, Cg-Foxl2 and Cg-Foxl2os (Fig. 4A and C). It should be noted that gene expressions are slightly disturbed at the beginning of the experiment when animals are transferred to different temperature environments (Fig. 4A and C).

At $28^{\circ} \mathrm{C}$ (Fig. 5A-C), gene expressions are disturbed throughout the whole experiment. Significant peaks of expression of $\mathrm{Cg}$-DMl and $\mathrm{Cg}$-SoxE appear later compared to data obtained for lower temperatures, in 36-dpf spat ( $U \leq 5, \mathrm{p}<0.05$ two-tailed; for instance for Cg-DMl, $U=0$ and 2 respectively when comparing with 35 and 37-dpf spat; not illustrated by letters on the graphs), again at the developmental stage when specimens are still devoid of gonads (Fig. 5B). Cg- $\beta$-catenin and Oyvlg exhibit no peak of expression (Fig. 5A) at this stage and thereafter. However, the trend observed at $25^{\circ} \mathrm{C}$ with a dominant male gene expression is confirmed at $28^{\circ} \mathrm{C}$ with Cg-DMl significantly more expressed than $\mathrm{Cg}-\mathrm{SoxE}(\mathrm{U}=3, \mathrm{p}<0.05$ two-tailed; stars indicate significant differences of expression between two genes), itself being more expressed than $\mathrm{Cg}-\beta$ - 
catenin ( $\mathrm{U}=0, \mathrm{p}<0.05$ two-tailed; stars indicate significant differences of expression between two genes).Some small non-significant peaks of expression are also observed, especially for Cg-DMl (Fig. 5A).Significant peaks of expression of Cg-Foxl2 and Cg-Foxl2os occur in 34/35-dpf spat ( $\mathrm{U}=5$ when comparing stage 33 with $34 \mathrm{dpf}$ for $\mathrm{Cg}$-Fox12; $\mathrm{p}<0.05$ two-tailed; not illustrated by letters on the graphs). Cg-Foxl2os expression now for the first time tends to be higher than $\mathrm{Cg}$ Fox12 expression, but the difference is not statistically significant (U=17) (Fig. 5C).

\section{Discussion}

In this study we report the effect of four different temperature levels $\left(18,22,25\right.$ and $\left.28^{\circ} \mathrm{C}\right)$ on sex determination, first gonadic differentiation and gametogenesis in C. gigas spat. For this purpose, spat were grown in controlled conditions of light, oxygen and food availability (a constant biomass of food was maintained in the tank over the time of the experiment) in order to discriminate only the influence of temperature.

\subsection{Temperature influences the first gonadic differentiation and gametogenesis}

In spat, increased temperatures accelerated the kinetics of first gonadic differentiation and gametogenesis. This was illustrated by (i) the increased number of gonadal tubules and collecting ducts as temperatures increased, (ii) for instance the presence of most of the germ cell line at $25^{\circ} \mathrm{C}$, while only undifferentiated germ cells were observed at $18^{\circ} \mathrm{C}$ and (iii) the earlier peaks of expressions of Oyvlg mRNA as temperature increased. High temperatures also stimulate the kinetics of gametogenesis in adult $C$. gigas (Fabioux et al., 2005). In the same way, high temperatures induce an increase of gonadal index in the horse-bearded mussel Modiolus barbatus (Mladineo et al., 2007) and accelerate spermatogenesis in the toad Bufo melanosticus (Parua Mondal et al., 2011). In contrast, in the mussel Mytilus edulis and the pearl oyster Pinctada imbricate, increased temperatures slow down gametogenesis, as energy is allocated to metabolism rather than reproduction (Urban, 2000; Fearman and Moltschaniwskyj, 2010). A better understanding of the effect of temperature on kinetics of first gonadic differentiation and gametogenesis in C. gigas is therefore critical, as very little is known on this topic in mollusks, and very different consequences can be observed among phyla but also even between mollusks themselves. 
In our study, temperatures of 25 and $28^{\circ} \mathrm{C}$ also slightly disturbed/delayed gonadic differentiation and gametogenesis as illustrated for instance by disturbed Oyvlg expression at the beginning of the experiment (and at $28^{\circ} \mathrm{C}$ thereafter). Nevertheless, the delay is later cancelled out and gametogenesis occurs to the end, as illustrated by the presence (although in low number) of differentiated germ cells. These results highlight therefore the particularly great ability of oysters to cope with changing environments in comparison with many well studied ectothermic vertebrates, in particular fish (Pankhurst and King, 2010). Indeed, in these species, temperature seems to stop rather than delay gonadic differentiation. For instance, in salmonids (Pankhurst and King, 2010), high temperatures (i) have been shown to have deleterious effects on reproductive development of female broodstocks of rainbow trout Oncorhynchus mykiss and Arctic charr Salvelinus alpinus, and (ii) inhibit spermiation in S. salar and O. mykiss. High temperatures also prevent gonadal maturation of the pikeperch Sander lucioperca (Hermelink et al., 2011).

Nevertheless, according to species and sex, the sensitivity threshold is different; gametogenesis is affected by a $4^{\circ} \mathrm{C}$ increase in the blue gourami Trichogaster trichopterus and male Cottus gobio, while it is impaired by a $8^{\circ} \mathrm{C}$ temperature increase in females C. gobio (Dorts et al., 2012).

Our study is the first one to deal with the kinetics of first gonadic differentiation and gametogenesis in C. gigas, taking into consideration the effects of temperature on these processes in spat. From a fundamental point of view, such information is important. Firstly because almost nothing is known about the first oyster's gonadic differentiation and gametogenesis in spat, apart from some information about (i) the migration of PGCs mentioned by some quite old studies (Galtsoff, 1964; Tardy, 1970; Lubet et al., 1976) and about (ii) the presence of undifferentiated germ cells observed in gonadal tubules in 90/120-dpf spat grown at $18^{\circ} \mathrm{C}$, by Naimi et al. (2009b). Secondly, it is commonly accepted that in oysters the kinetics of development, gonadic differentiation and gametogenesis are all correlated. Yet, reality is far from being clear. Indeed in the present study, as was expected, increased temperatures accelerated spat development, as illustrated by an increase in the size of animals grown at $28^{\circ} \mathrm{C}$ compared to those kept at $18^{\circ} \mathrm{C}$ for instance. But the biggest animals were not always the ones showing the most differentiated gonad or advanced gametogenesis (unpublished data). Finally, from a practical point of view, a better understanding of the kinetics of gonadic differentiation and gametogenesis in oyster spat will 
help to better understand the physiology of the animals when they are transferred to the field and are affected by high mortality rates.

\subsection{Temperature influences spat sex ratio}

Studying the effect of temperature on spat sex ratios is a first step to better characterize the type of sex determination of oysters. This environmental factor is also one of the most easily modulated parameters in hatcheries, for instance to orientate the sex development in animals. In oyster spat, temperatures from 18 to $28^{\circ} \mathrm{C}$ induced a switch in sex ratios, with a significant effect observed between 18 and $28^{\circ} \mathrm{C}$. This is the first time that influence of temperature on sex ratio has been documented for spat. In adults, biased sex ratios have been observed in the field under different environmental conditions (food, temperature) and a one-year conditioning at $8^{\circ} \mathrm{C}$ has been mentioned to induce a male-biased sex ratio (1:1.6) (Fabioux et al., 2005). Thus, our results strongly reinforce the hypothesis of the existence of a TSD in the Pacific oyster. Because genetic control has also been previously mentioned (Guo et al., 1998; Hedrick and Hedgecock, 2010), $C$. gigas may then exhibit a mixed sex determination (GSD+TSD), as can be observed for many fish and amphibians (Valenzuela et al., 2003; Wedekind and Stelkens, 2010). Our results also allow to hypothesize about the patterns of temperature-sensitivity of the Japanese oyster, even if these patterns are highly variable among species with TSD. Indeed, high temperatures of incubation during the development lead to the production of male embryos (pattern Ia: FM) for most turtle species such as Trachemys scripta, Lepidochelis olivacea or Chrysemys picta (Shoemaker and Crews, 2009) and for all fish with TSD (Ospina-Álvarez and Piferrer, 2008). In contrast, high temperature leads to the development of females (pattern Ib : MF) for most lizards (Hulin et al., 2009). Some other species among crocodiles, turtles such as Chelydra serpentina, lizards and squamates as the gecko Eublepharis macularius exhibit another mode of TSD, with extreme cool and warm temperatures producing females while intermediate temperatures induce the development of males (Pattern II: FMF) (Shoemaker and Crews, 2009). Recently another pattern has been proposed for the lizard Calotes versicolor, with $100 \%$ males produced at low $\left(25.5^{\circ} \mathrm{C}\right)$ as well as very high $\left(34^{\circ} \mathrm{C}\right)$ incubation temperatures and $100 \%$ females produced at very low $\left(23.5^{\circ} \mathrm{C}\right)$ and high $\left(31.5^{\circ} \mathrm{C}\right)$ temperatures (Pattern III: FMFM) (Inamdar-Doddamani et al., 2012). In C. gigas spat (which is the object of our study), the significant change from a female to a malebiased sex ratio between 18 and $28^{\circ} \mathrm{C}$ may suggest a pattern $\mathrm{Ib}(\mathrm{FM})$ as observed for instance in 
fish. However, the hypothesis of a MFM pattern cannot be excluded, considering that adult sex ratios are in favor of males at $8^{\circ} \mathrm{C}$ (Fabioux et al., 2005).Very little is known about the physiological mechanisms underlying such diverse patterns. In oysters, sex ratios are in favor of females when food availability conditions are favorable (Lango-Reynoso et al., 1999; ChávezVillalba et al., 2011). This may help to store carbonates and lipids, which are critical for the formation of female germ cell lineage (Soletchnik et al., 1997). Males would then be preferentially found when unfavorable conditions prevail, suggesting that their metabolism may require less energy than that of females. In oysters, temperatures of $8^{\circ} \mathrm{C}$ (Fabioux et al., 2005), $25^{\circ} \mathrm{C}$ and $28^{\circ} \mathrm{C}$ (our study) may produce more males, as they are not reflective of optimal conditions. This could be illustrated here by disturbed sex-determining gene expressions and gonadic differentiation for some individuals, and also by an increased number of simultaneous hermaphrodites, as already observed by Lango-Reynoso et al. (2006) when temperature increases in spring. Finally, it may be surprising to obtain mainly female spat at $18^{\circ} \mathrm{C}$, as oysters are usually considered as protandric animals. This point highlights the complexity of environmental influences on oyster sex determination and may suggest in the frame of the present work additional impact of optimal conditions of food availability.

\subsection{Temperature influences the expression of oyster sex determination candidate genes} The mRNA expression profiles of five candidate genes involved in the oyster adult sexdetermining pathway (Cg-Fox12, Cg-Fox12os, $\mathrm{Cg}$-DMl, $\mathrm{Cg}$-SoxE and $\mathrm{Cg}$ - $\beta$-catenin) and of the germ cell marker Oyvlg have been studied by real-time PCR at each temperature. Such expression profiles should help to develop better hypotheses about the type of sex determination of $C$. gigas, which is still very poorly known as in other mollusks. It could also significantly enrich what scarce information is currently available about TSD species among vertebrates and invertebrates. However, when efficient heterologous antibodies are available for invertebrate species, a study of protein expression will be indispensable to obtain more accurate data about hypotheses on sex determination in oyster.

In the present study the developmental stage exhibiting a peak of expression of Oyvlg and devoid of gonad was considered as a reference, a key time of gonadic differentiation in order to only 
measure the effect of different temperatures, and not the effect of different developmental stages on these gene expressions at each temperature.

Cg-Fox12 and Cg-Fox12os levels statistically increased respectively in spat aged 40, 37, 32 and $34 \mathrm{dpf}$ at $18,22,25$ and $28^{\circ} \mathrm{C}$, while $\mathrm{Cg}$-SoxE, Cg-DMl, Cg- $\beta$-catenin and Oyvlg significant peaks of expressions occurred respectively in spat aged 44, 37, 34 and $36 \mathrm{dpf}$. These mRNA expression profiles may suggest a time window of sex determination in spat at around 40-44 dpf at $18^{\circ} \mathrm{C}$. This is in agreement with previous studies which suggest that sex determination may occur at around 45-60 dpf (Naimi et al., 2009b). Although increased temperatures accelerate (and shorten) the kinetics of sex determination as they accelerate (and shorten) the kinetics of first gonadic differentiation, the four-day time window in the present study is particularly short compared to the 15 days at $18^{\circ} \mathrm{C}$ mentioned by Naimi et al. (2009b). This may be explained by optimal conditions of food availability prevailing in the frame of the present work.

The peaks of mRNA expression of $\mathrm{Cg}$-Foxl2, $\mathrm{Cg}$-Foxl2os, $\mathrm{Cg}-\mathrm{SoxE}, \mathrm{Cg}-\mathrm{DMl}$, and $\mathrm{Cg}-\beta$-catenin observed in our study also suggest that these factors may intervene in the sex determination cascade of $C$. gigas spat and adults (Naimi et al., 2009a; b; Santerre et al., 2012 and unpublished data). For each temperature, $\mathrm{Cg}$-Foxl2 and $\mathrm{Cg}$-Fox12os expressions always significantly peaked before other sex-determining genes in spat. This is in agreement with previous results obtained in adults, showing peak expressions of both genes in mature stages, before Cg-SoxE, Cg-DMl peak expressions in stage 0 of the following cycle (Santerre et al., unpublished data).

As in adults, our results exhibit a spat sex determination cascade with a balance of mRNA expression between male and female orthologs, but for the first time in oyster they also highlight an influence of temperature. Indeed at 18 and $22^{\circ} \mathrm{C}$, when a female-biased sex ratio is observed, significant differences of mRNA expression levels are always in favor of female orthologs $(\mathrm{Cg}$ Fox 12 at $18^{\circ} \mathrm{C}$ and $\mathrm{Cg}-\beta$-catenin at $22^{\circ} \mathrm{C}$ ). As in adult oysters, this may suggest an involvement of these actors in the female sex determination process during initial ovarian differentiation (Santerre et al., 2012; unpublished data). In contrast, at $28^{\circ} \mathrm{C}$, when a male-biased sex ratio is observed, significant differences of mRNA expression levels are in favor of male orthologs such as $\mathrm{Cg}$-SoxE and $\mathrm{Cg}$-DMl. Both may induce a male gonadic differentiation, as suggested in adults 
(Naimi et al., 2009b; Santerre et al., unpublished data). At this temperature this was also the first time that $\mathrm{Cg}$-Foxl2os expression tended to be superior to $\mathrm{Cg}$-Foxl2 expression, although the difference was not statistically different. As mentioned by Santerre et al. (2012) concerning adults, $\mathrm{Cg}$-Fox12 expression could be down-regulated by $\mathrm{Cg}$-Fox12os to participate in male gonadic differentiation. At $25^{\circ} \mathrm{C}$, sex ratio was only slightly biased towards males and mRNA expressions were not significantly different, whatever the gene considered. This could go to suggest that this temperature may be close to the level at which the switch between females and males production occurs. Such influence of temperature on the mRNA expression profiles of the sex-determining genes has already been mentioned for other species with TSD, for instance Fox12 in T. scripta (Shoemaker-Daly et al., 2010), C. serpentine (Rhen et al., 2007) and Japanese flounder (Yamaguchi et al., 2007) and Dmrt1 and Sox9 in L. olivacea and T. scripta (Torres Maldonado et al., 2002; Shoemaker et al., 2007). In these species, Fox12 mRNA expression increases at female-promoting egg incubation temperature while Dmrt1 and Sox 9 mRNA expressions increase at male-promoting temperature. Therefore the authors suggest an involvement of these factors, either in early gonadic differentiation, or in sex determination. Such role may also be hypothesized for the oyster orthologs but evidencing this would require protein expression studies.

\section{Conclusions}

Our results address for the first time an environmental influence associated to a genetic control on oyster's sex determination. They also make it possible to refine hypotheses about the sexdetermining time window and molecular cascade of $C$. gigas during the development of the animal. Finally, they are the first to consider the kinetics of first gonadic differentiation and gametogenesis and the effect of temperature on these processes in spat.

\section{Acknowledgements}

This research was supported by the European Project "Reproseed" (FP7-KBBE-2009-3). The authors are grateful to Béatrice Adeline, Luc Lebrun and Isabelle Queau for their technical assistance, to Arnaud Lemaréchal and Mathieu Paiola for their help in the treatment of some samples and to Christophe Joubel for the English proofreading. Part of the experiments was done 
at the Proteogen plateform (IBFA, SF ICORE, UCBN) and at the experimental hatchery of Argenton (Ifremer). Christelle Santerre's study is supported by a grant from the 'Ministère de l'Enseignement Supérieur et de la Recherche' (MESR).

\section{Legend of the figures}

Figure 1: Histograms of sex ratio of spat of the oyster Crassostreagigas grown at four different temperature levels $\left(18,22,25\right.$ and $\left.28^{\circ} \mathrm{C}\right)$. Number of animals with differentiated sex (n) used at each temperature is indicated below each histogram. At 18 and $22^{\circ} \mathrm{C}$, sex ratios are biased towards females while they are male-biased at 25 and $28^{\circ} \mathrm{C}$. Only female biased sex ratio observed at $18^{\circ} \mathrm{C}$ is significantly different from male biased sex ratio observed at $28^{\circ} \mathrm{C}\left(\chi^{2}\right.$ tests; $\mathrm{p}<0.05$, the star indicates significant differences of expression between the two temperatures). Simultaneous hermaphrodites are also observed above $25^{\circ} \mathrm{C}$. (A, B and C) Histological pictures illustrating random spat gametogenesis inside collecting ducts. (A) Female grown at $18^{\circ} \mathrm{C}$ with few pre-vitellogenic oocytes surrounded by somatic cells. (B) Male grown at $22^{\circ} \mathrm{C}$ with spermatogonia and spermatocytes. (C) Simultaneous hermaphrodite grown at $28^{\circ} \mathrm{C}$, exhibiting in the same tubule both female germ cells (at the periphery) and male germ cells (in the centre). (D) Female grown at $28^{\circ} \mathrm{C}$, showing vitellogenic oocytes. Dpf: days post-fertilisation; Oog: oogonia; pvO: pre-vitellogenic oocyte; spc: spermatocyte; vO: vitellogenic oocyte. Herma: hermaphrodites; $\bigcirc$ : females; $\widehat{0}:$ males.

Figure 2: Cg-SoxE, Cg-DMI, Cg-ß-catenin and Oyvlg (A) and Cg-Foxl2 and Cg-Foxl2os (C) mRNA temporal expressions relative to EF1 $\alpha$ measured by real-time RT-PCR in spat grown at $18^{\circ} \mathbf{C}$. Total RNAs were isolated from 6 pools of 10 animals. QR: Relative Quantity, arbitrary units. Values are mean \pm SEM. Statistical analysis: 2-tailed Mann-Whitney U-test (significant for $\mathrm{p}<0.05)$. A significant peak of expression is observed for Oyvlg, $\mathrm{Cg}-\beta$-catenin, $\mathrm{Cg}$-SoxE and $\mathrm{Cg}$ DMl in 44-dpf spat ( $U \leq 5, \mathrm{p}<0.05$ two-tailed, not illustrated by letters on the graphs), after CgFox12 and Cg-Fox12os expression which significantly increase at $40 \mathrm{dpf}(\mathrm{U} \leq 5, \mathrm{p}<0.05$ two-tailed, not illustrated by letters on the graphs). $\mathrm{Cg}$ - $\beta$-catenin expression tends to be higher than the expression levels of male orthologs, but the difference is not statistically different (for instance $\mathrm{U}=8$ for comparison of $\mathrm{Cg}$-SoxE and $\mathrm{Cg}-\mathrm{DMl}$ with $\mathrm{Cg}-\beta$-catenin). $\mathrm{Cg}$-Foxl2 is significantly more expressed than $\mathrm{Cg}$-Fox12os, its natural antisense transcript $(\mathrm{U}=3, \mathrm{p}<0.05$ two-tailed, stars indicate 
significant differences of expression between two genes). (B) Histological section in spat exhibiting a peak of Oyvlg, of the area where the gonad is expected but which only shows the kidney $(\mathrm{K})$ and digestive gland (DG).

Figure 3: Cg-SoxE, Cg-DMl, Cg- $\beta$-catenin and Oyvlg (A) and Cg-Foxl2 and Cg-Foxl2os (C) mRNA temporal expressions relative to EF1 $\alpha$ measured by real-time RT-PCR in spat grown at $22^{\circ} \mathrm{C}$. Total RNAs were isolated from 6 pools of 10 animals. QR: Relative Quantity, arbitrary units. Values are mean \pm SEM. Statistical analysis: 2-tailed Mann-Whitney U-test (significant for $\mathrm{p}<0.05)$. A significant peak of expression is observed for Oyvlg, Cg- $\beta$-catenin, $\mathrm{Cg}$-SoxE and $\mathrm{Cg}$ DMl in 37-dpf spat ( $\leq \leq 5, \mathrm{p}<0.05$ two-tailed), after Cg-Foxl2 and Cg-Foxl2os expression which significantly increase at 31-34 dpf $(\mathrm{U} \leq 5, \mathrm{p}<0.05$ two-tailed; not illustrated by letters on the graphs). $\mathrm{Cg}-\beta$-catenin expression is significantly higher than male orthologs $\mathrm{Cg}$-SoxE ( $\mathrm{U}=5$, $\mathrm{p}<0.05$ two-tailed) and $\mathrm{Cg}$-DMl expressions ( $\mathrm{U}=4, \mathrm{p}<0.05$ two-tailed, stars indicate significant differences of expression between two genes). Cg-Foxl2 expression is not significantly different than those of its NAT $(\mathrm{U}=10)$, although the former tends to be higher than the latter. (B) Histological section in spat exhibiting a peak of Oyvlg, of the area where the gonad is expected but which only shows the kidney (K), hemolymphatic vessel (V) and digestive gland (DG).

Figure 4: Cg-SoxE, Cg-DMl, Cg- $\beta$-catenin and Oyvlg (A) and Cg-Foxl2 and Cg-Foxl2os (C) mRNA temporal expressions relative to EF1 $\alpha$ measured by real-time RT-PCR in spat reared at $25^{\circ} \mathrm{C}$. Total RNAs were isolated from 6 pools of 10 animals. QR: Relative Quantity, arbitrary units. Values are mean \pm SEM. Statistical analysis: 2-tailed Mann-Whitney U-test (significant for $\mathrm{p}<0.05$ ). A significant peak of expressions is observed for Oyvlg, $\mathrm{Cg}-\beta$-catenin, Cg-SoxE and Cg-DMl in 34-dpf spat, after Cg-Foxl2 and Cg-Foxl2os expressions which significantly increase at $32 \mathrm{dpf}(\mathrm{U} \leq 5, \mathrm{p}<0.05$ two-tailed, not illustrated by letters on the graphs). The general trend shows male gene ( $\mathrm{Cg}$-DMl and $\mathrm{Cg}$-Sox E) expression higher than the female gene expression ( $\mathrm{Cg}-\beta$-catenin) but differences are not statistically significantly (for instance $\mathrm{U}$ $=16$ for comparison of $\mathrm{Cg}$-DMl with $\mathrm{Cg}-\beta$-catenin). $\mathrm{Cg}$-Foxl2 and $\mathrm{Cg}$-Foxl2os expression levels are not significantly different either $(\mathrm{U}=17)$.Gene expressions are slightly disturbed at the beginning of the experiment when animals are transferred to different temperatures. (B) 
Histological section in spat exhibiting a peak of Oyvlg, of the area where the gonad is expected but which only shows the digestive gland (DG), hemolymphatic vessel (V) and intestine (I).

Figure 5: Cg-SoxE, Cg-DMl, Cg-ß-catenin and Oyvlg (A) and Cg-Foxl2 and Cg-Foxl2os (C) mRNA temporal expressions relative to EF1a measured by real-time RT-PCR in spat reared at $28^{\circ} \mathrm{C}$. Total RNAs were isolated from 6 pools of 10 animals. QR: Relative Quantity, arbitrary units. Values are mean \pm SEM. Statistical analysis: 2-tailed Mann-Whitney U-test (significant for $\mathrm{p}<0.05$ ). A significant peak of expression is observed for $\mathrm{Cg}-\mathrm{SoxE}$ and $\mathrm{Cg}-\mathrm{DMl}$ in 36-dpf spat ( $\mathrm{U} \leq 5, \mathrm{p}<0.05$ two-tailed), after $\mathrm{Cg}$-Fox12 and $\mathrm{Cg}$-Foxl2os expression which significantly increase at 34-35 $\mathrm{dpf}(\mathrm{U} \leq 5, \mathrm{p}<0.05$ two-tailed; not illustrated by letters on the graphs). Cg-DMl is significantly more expressed than $\mathrm{Cg}$-SoxE ( $U=3, \mathrm{p}<0.05$ two-tailed; stars indicate significant differences of expression between two genes), itself more expressed than $\mathrm{Cg}$ $\beta$-catenin $(\mathrm{U}=0, \mathrm{p}<0.05$ two-tailed; stars indicate significant differences of expression between two genes). Cg-Fox12os expression tends to be superior to Cg-Foxl2 expression (Fig. 5C) but the difference is not statistically significant $(\mathrm{U}=17)$. Gene expressions are disturbed at the beginning

of the experiment when animals are transferred to different temperatures and for Oyvlg and Cg- $\beta$ catenin thereafter. (B) Histological section in spat at the 'reference stage', of the area where the gonad is expected but which only shows the digestive gland (DG), kidney (K), hemolymphatic vessel (V) and intestine (I).

\section{Table 1: Primers used for real-time PCR.}

AS: antisense primer; S: sense primer. Genbank accession numbers are indicated for each gene.

\section{Table 2: Criteria used to assess progress of gonadic differentiation and gametogenesis.}

Criteria used to assess kinetics of gonadic differentiation are the number of collecting ducts and of gonadal tubules and for gametogenesis, the number and proportions of type of germ cells observed. <: inferior; >: superior; \%: percentage; Absence: $(-)$; Presence and abundance: $(+)<$ $(++)<(+++)$.

Table 3: Kinetics of first gonadic differentiation and gametogenesis in spat of the same age, arbitrarily $49 \mathrm{dpf}$, at four different temperature levels. Criteria used to assess the kinetics of (i) gonadic differentiation are the number of collecting ducts and of gonadal tubules and (ii) 
gametogenesis, the number and type of germ cells observed [Absence: (-); Presence and abundance: $(+)<(++)<(+++)$ ]. Increased temperatures accelerate gonadic differentiation and gametogenesis in parallel with the development of the animal. Microscope magnifications: x 10 and x 40. cd: collecting ducts; dpf: days post-fertilisation; gt: gonadic tubules; No: number; Oog: oogonias; pvO: pre-vitellogenic oocytes; PGC: primordial germ cells; Spc: spermatocytes; Spg: spermatogonias; Spt: spermatids; Sptz: spermatozoids; UGC: undifferentiated germ cells; vO: vitellogenic oocytes.

\section{References}

Chávez-Villalba, J., Soyez, C., Huvet, A., Gueguen, Y., Lo, C., Moullac, G.L., 2011.

Determination of Gender in the Pearl Oyster Pinctada margaritifera. J. Shellfish Res. 30, 231240.

Coe, W.R., 1936. Environment and sex in the oviparous oyster Ostrea virginica. Biol. Bull. 71, 353.

Dorts, J., Grenouillet, G., Douxfils, J., Mandiki, S., Milla, S., Silvestre, F., Kestemont, P., 2012. Evidence that elevated water temperature affects the reproductive physiology of the European bullhead Cottus gobio. Fish Physiol. and Biochem. 38, 389-399.

Fabioux, C., Huvet, A., Le Souchu, P., Le Pennec, M., Pouvreau, S., 2005. Temperature and photoperiod drive Crassostrea gigas reproductive internal clock. Aquaculture 250, 458-470.

Fearman, J., Moltschaniwskyj, N.A., 2010. Warmer temperatures reduce rates of gametogenesis in temperate mussels, Mytilus galloprovincialis. Aquaculture 305, 20-25.

Gabe, M., 1968. Techniques histologiques. Masson Paris.

Galtsoff, P., 1964. The american oyster Crassostrea virginica Gmelin. J. Exp. Mar. Biol. Ecol. 64, 11-28.

Guo, X., Hedgecock, D., Hershberger, W.K., Cooper, K., Allen Jr, S.K., 1998. Genetic determinants of protandric sex in the Pacific oyster, Crassostrea gigas Thunberg. Evolution 394402.

Guo, X., Li, Q., Wang, Q.Z., Kong, L.F., 2012. Genetic Mapping and QTL Analysis of GrowthRelated Traits in the Pacific Oyster. Mar. Biotechnol. 14, 218-226.

Hedrick, P.W., Hedgecock, D., 2010. Sex determination: genetic models for oysters. J. Hered. $101,602-611$. 
Hermelink, B., Wuertz, S., Trubiroha, A., Rennert, B., Kloas, W., Schulz, C., 2011. Influence of temperature on puberty and maturation of pikeperch, Sander lucioperca. Gen. Comp. Endocrinol. $172,282-292$.

Hulin, V., Delmas, V., Girondot, M., Godfrey, M., Guillon, J.-M., 2009. Temperature-dependent sex determination and global change: are some species at greater risk? Oecologia 160, 493-506.

Inamdar-Doddamani, L.S., Vani, V., Seshagiri, P.B., 2012. A tropical oviparous lizard, Calotes versicolor, exhibiting a potentially novel FMFM pattern of temperature-dependent sex determination. J. Exp. Zool. Part A: Ecol. Genet. Physiol. 317A, 32-46.

Janzen, F.J., 1994. Climate Change and Temperature-Dependent Sex Determination in Reptiles. PNAS 91, 7487-7490.

Korpelainen, H., 1990. Sex ratios and conditions required for environmental sex determination in animals. Biol. Rev. 65, 147-184.

Lango-Reynoso, F., Chavez-Villaba, J., Le Pennec, M., 2006. Reproductive patterns of the Pacific oyster Crassostrea gigas in France. Inver. Rep. Dev. 49, 41-50.

Lango-Reynoso, F., Devauchelle, N., Le Pennec, M., Hatt, P.-J., 1999. Elements of reproductive strategy in oysters, Crassostrea gigas, from the "Rade de Brest", France. Inver. Rep. Dev. 36, $141-144$.

Lubet, P., Herlin-Houtteville, P., Mathieu, M., 1976. La lignée germinale des mollusques pélécypodes. Origine et évolution. Bull. Soc. Zool. France 101, 22-27.

Manolakou, P., Lavranos, G., Angelopoulou, R., 2006. Molecular patterns of sex determination in the animal kingdom: a comparative study of the biology of reproduction. Reprod. Biol. Endocrinol. 4, 59.

Mladineo, I., Peharda, M., Orhanović, S., Bolotin, J., Pavela-Vrančić, M., Treursić, B., 2007. The reproductive cycle, condition index and biochemical composition of the horse-bearded mussel Modiolus barbatus. Helgoland Mar. Res. 61, 183-192.

Naimi, A., Martinez, A.-S., Specq, M.-L., Diss, B., Mathieu, M., Sourdaine, P., 2009a. Molecular cloning and gene expression of $\mathrm{Cg}$-Fox12 during the development and the adult gametogenetic cycle in the oyster Crassostrea gigas. Comp. Biochem. Physiol. B, Biochem. Mol. Biol. 154, 134-142.

Naimi, A., Martinez, A.-S., Specq, M.-L., Mrac, A., Diss, B., Mathieu, M., Sourdaine, P., 2009 b. Identification and expression of a factor of the DM family in the oyster Crassostrea gigas. Comp. Biochem. Physiol., Part A Mol. Integr. Physiol. 152, 189-196. 
Ospina-Álvarez, N., Piferrer, F., 2008. Temperature-Dependent Sex Determination in Fish Revisited: Prevalence, a Single Sex Ratio Response Pattern, and Possible Effects of Climate Change. PLoS ONE 3, 7.

Pankhurst, N.W., King, H.R., 2010. Temperature and salmonid reproduction: implications for aquaculture. J. Fish Biol. 76, 69-85.

Parua Mondal, S., Debnath, J.M., Ghosh, D., 2011. Effect of an increase in environmental temperature on testicular androgenesis and spermatogenesis in toad (Bufo melanostictus) during hibernating season. Zoo Biol. 30, 681-688.

Pradeep, P.J., Srijaya, T.C., Papini, A., Chatterji, A.K., 2012. Effects of triploidy induction on growth and masculinization of red tilapia [Oreochromis mossambicus (Peters, 1852) $\times$ Oreochromis niloticus (Linnaeus, 1758)]. Aquaculture 344-349, 181-187.

Rhen, T., Metzger, K., Schroeder, A., Woodward, R., 2007. Expression of Putative SexDetermining Genes during the Thermosensitive Period of Gonad Development in the Snapping Turtle, Chelydra serpentina. Sex. Dev. 1, 255-270.

Rico-Villa, B., Le Coz, J.R., Mingant, C., Robert, R., 2006. Influence of phytoplankton diet mixtures on microalgae consumption, larval development and settlement of the Pacific oyster Crassostrea gigas (Thunberg). Aquaculture 256, 377-388.

Rico-Villa, B., Woerther, P., Mingant, C., Lepiver, D., Pouvreau, S., Hamon, M., Robert, R., 2008. A flow-through rearing system for ecophysiological studies of Pacific oyster Crassostrea gigas larvae. Aquaculture 282, 54-60.

Rico-Villa, B., Bernard, I., Robert, R., Pouvreau, S., 2010. A Dynamic Energy Budget (DEB) growth model for Pacific oyster larvae, Crassostrea gigas. Aquaculture 305, 84-94.

Santerre, C., Sourdaine, P., Martinez, A.-S., 2012. Expression of a Natural Antisense Transcript of Cg-Fox12 during the Gonadic Differentiation of the Oyster Crassostrea gigas : First Demonstration in the Gonads of a Lophotrochozoa Species. Sex. Dev. 6, 210-221.

Shoemaker, C., Ramsey, M., Queen, J., Crews, D., 2007. Expression of Sox9, Mis, and Dmrt1 in the gonad of a species with temperature-dependent sex determination. Dev. Dyn. 236, 10551063.

Shoemaker, C.M., Crews, D., 2009. Analyzing the coordinated gene network underlying temperature-dependent sex determination in reptiles. Semin. Cell Dev. Biol. 20, 293-303.

Shoemaker-Daly, C.M., Jackson, K., Yatsu, R., Matsumoto, Y., Crews, D., 2010. Genetic network underlying temperature-dependent sex determination is endogenously regulated by temperature in isolated cultured Trachemys scripta gonads. Dev. Dyn. 239, 1061-1075. 
Soletchnik, P., Razet, D., Geairon, P., Faury, N., Goulletquer, P., 1997. Écophysiologie de la maturation sexuelle et de la ponte de l'huître creuse Crassostrea gigas: réponses métaboliques (respiration) et alimentaires (filtration, absorption) en fonction des différents stades de maturation. Aquat. Living Resour. 10, 177-185.

Tardy, M.J., 1970. Organogenèse de 1'appareil génital chez les Mollusques. Bull. Soc. Zool. France 95, 407-427.

Torres Maldonado, L.., Landa Piedra, A., Moreno Mendo a, ., Ma rmole o Valencia, ., Me a Mart ne , ., Merchant Larios, H., 2002. Expression profiles of Dax1, Dmrt1, and Sox9 during temperature sex determination in gonads of the sea turtle Lepidochelys olivacea. Gen. Comp. Endocrinol. 129, 20-26.

Urban, H.-J., 2000. Culture potential of the pearl oyster (Pinctada imbricata) from the Caribbean : I. Gametogenic activity, growth, mortality and production of a natural population. Aquaculture 189, 361-373.

Valenzuela, N., Adams, D.C., Janzen, F.J., 2003. Pattern Does Not Equal Process: Exactly When Is Sex Environmentally Determined? Amer. Nat. 161, 676-683.

Wedekind, C., Stelkens, R.B., 2010. Tackling the diversity of sex determination. Biol. Lett. 6, 79.

Yamaguchi, T., Yamaguchi, S., Hirai, T., Kitano, T., 2007. Follicle-stimulating hormone signaling and Fox12 are involved in transcriptional regulation of aromatase gene during gonadal sex differentiation in Japanese flounder, Paralichthys olivaceus. Biochem. Biophys. Res. Commun. 359, 935-940. 
Table 1

\begin{tabular}{|c|c|c|c|}
\hline Factors & Genbank accession numbers & Primer names & Sequences (5'-3') \\
\hline \multirow[t]{2}{*}{ Oyvlg } & \multirow[t]{2}{*}{ AY423380.1 } & VS-S9 & TCCCCGAGGAGATTCAGA \\
\hline & & VS-AS9 & ACGTCAGTGCAAGCACCA \\
\hline \multirow[t]{2}{*}{ Cg-SoxE } & \multirow[t]{2}{*}{$\mathrm{JX040450.1}$} & SoxEqPCRS1 & GCCATTCAAGGAGAAAACGA \\
\hline & & SoxEqPCRAS1 & TGTAAGAGCTGGTCCAGGATG \\
\hline \multirow[t]{2}{*}{ Cg-DMI } & \multirow[t]{2}{*}{ EU046234.1 } & DMS & CCATGGAGTGGTGTCCGC \\
\hline & & DMASB & GTTGCCTTTCTGCTATCAGGG \\
\hline \multirow{2}{*}{$\begin{array}{l}\text { Cg-Foxl2 / } \\
\text { Cg-Foxl2os }\end{array}$} & \multirow{2}{*}{$\begin{array}{l}\text { FJ768956.1 / } \\
\text { JN896625.1 }\end{array}$} & FoxS7 & AATATCAGGGATGGGCACAA \\
\hline & & FoxAS3 & TCCTTGGGTGCAGGAACTA \\
\hline \multirow[t]{2}{*}{ Cg- $\beta$-Catenin } & \multirow[t]{2}{*}{ JX121092.1 } & $\beta$ CatqPCRS1 & CCATGATGGTTCACCAGTTG \\
\hline & & $\beta$ CatqPCRAS1 & ACAGCGAGTGGTCTCCAAGT \\
\hline \multirow[t]{2}{*}{ EF1 $\alpha$} & \multirow[t]{2}{*}{ AB122066.1 } & qfElong1 & ACCACCCTGGTGAGATCAAG \\
\hline & & qrElong1 & ACGACGATCGCATTTCTCTT \\
\hline
\end{tabular}




\section{Table 2}

\begin{tabular}{|c|c|c|}
\hline Criteria & Range & Symbol \\
\hline Number of gonadal tubules & $x<1$ & + \\
1 to 2 & + \\
2 to 5 & ++ \\
& $x>5$ & +++ \\
\hline Number of collecting ducts & $x<1$ & - \\
\hline Number of germ cells in collecting ducts & 1 to 2 & + \\
\hline Proportion of each type of germ cells & 2 to 5 & ++ \\
\hline & $x>5$ & +++ \\
\hline & 5 to 10 & + \\
\hline & 10 to 20 & ++ \\
\hline & $x>20$ & +++ \\
\hline & $x>20 \%$ & ++ \\
\hline & & ++ \\
\hline
\end{tabular}


Table 3

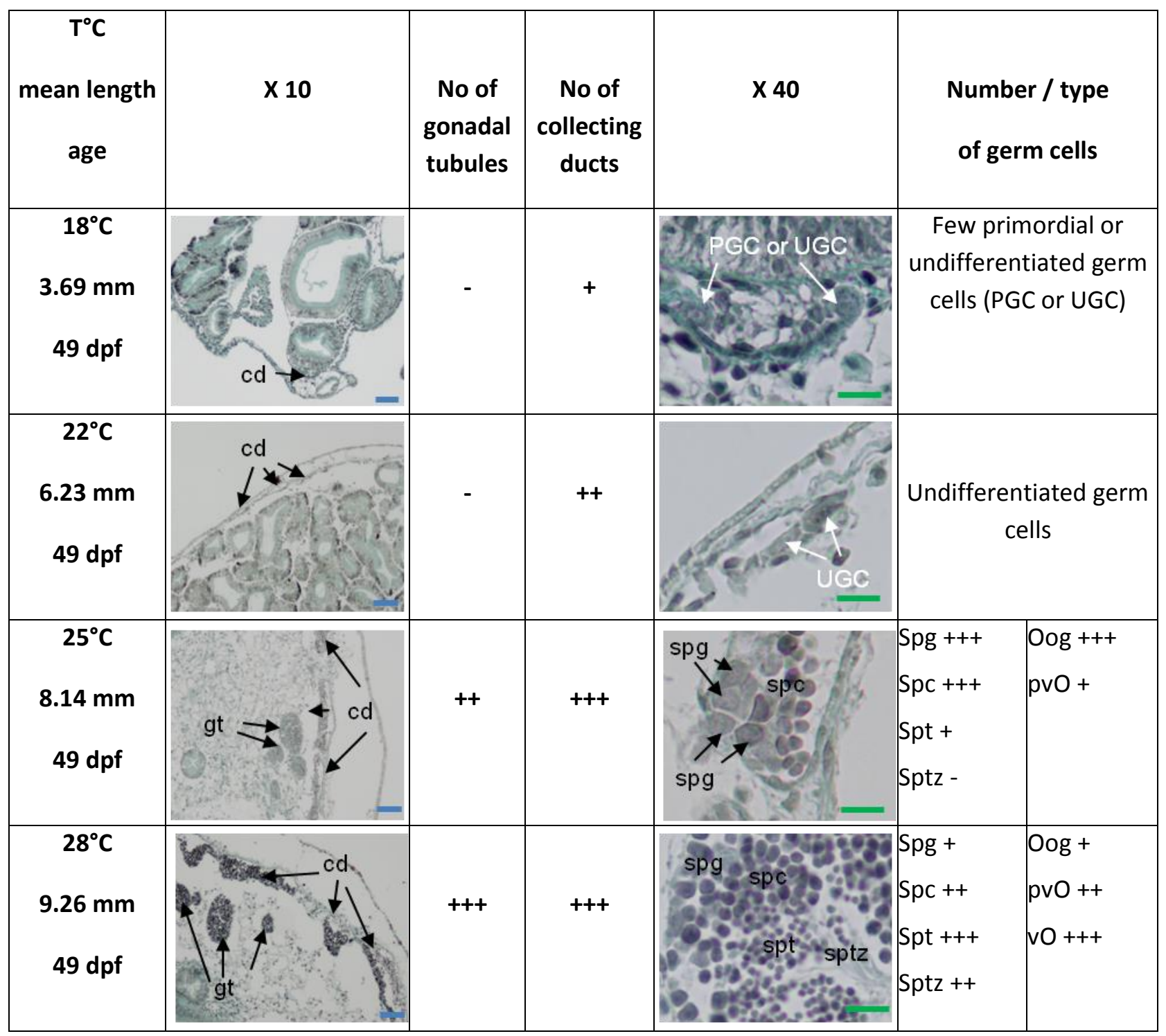




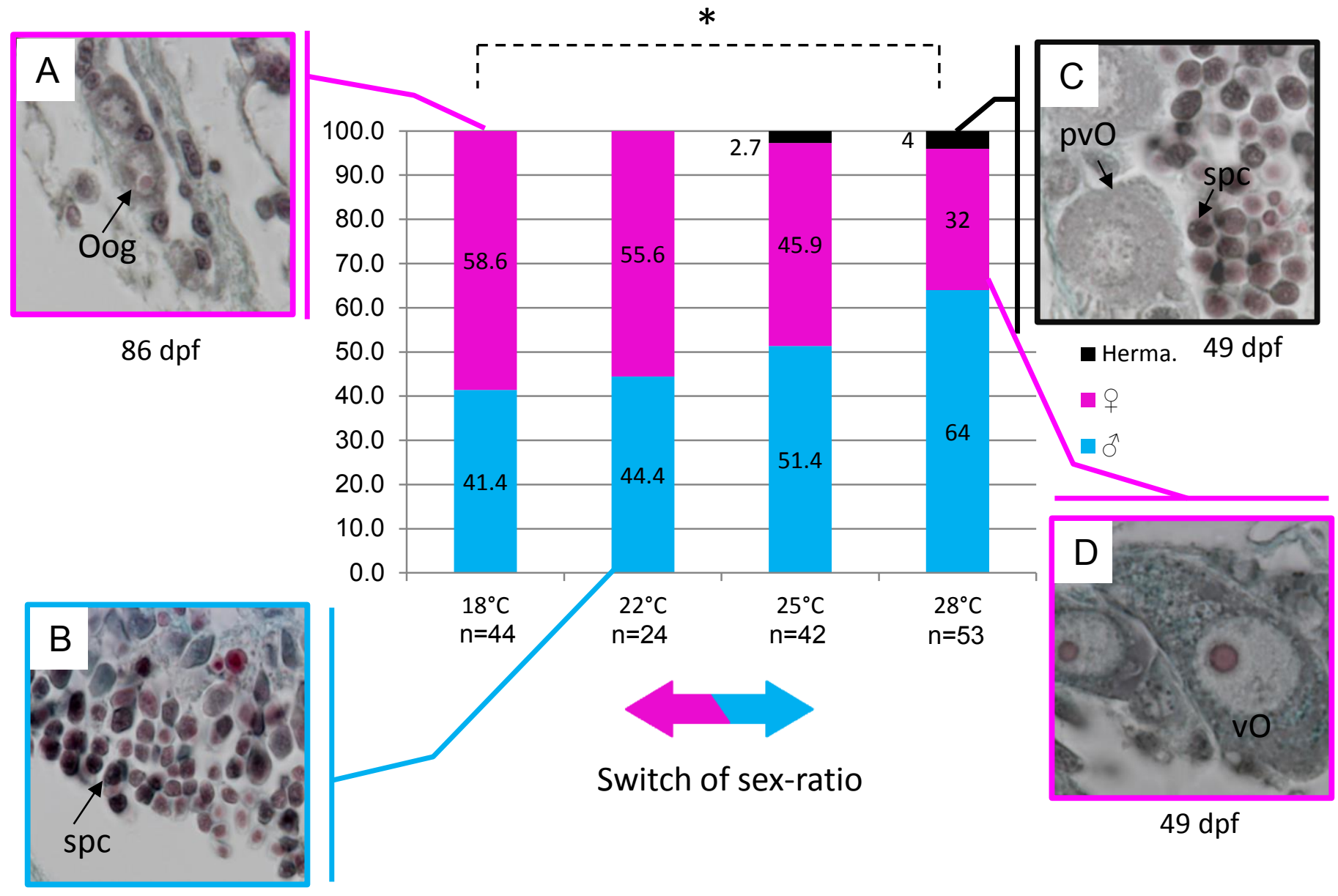

$56 \mathrm{dpf}$

Figure 1 


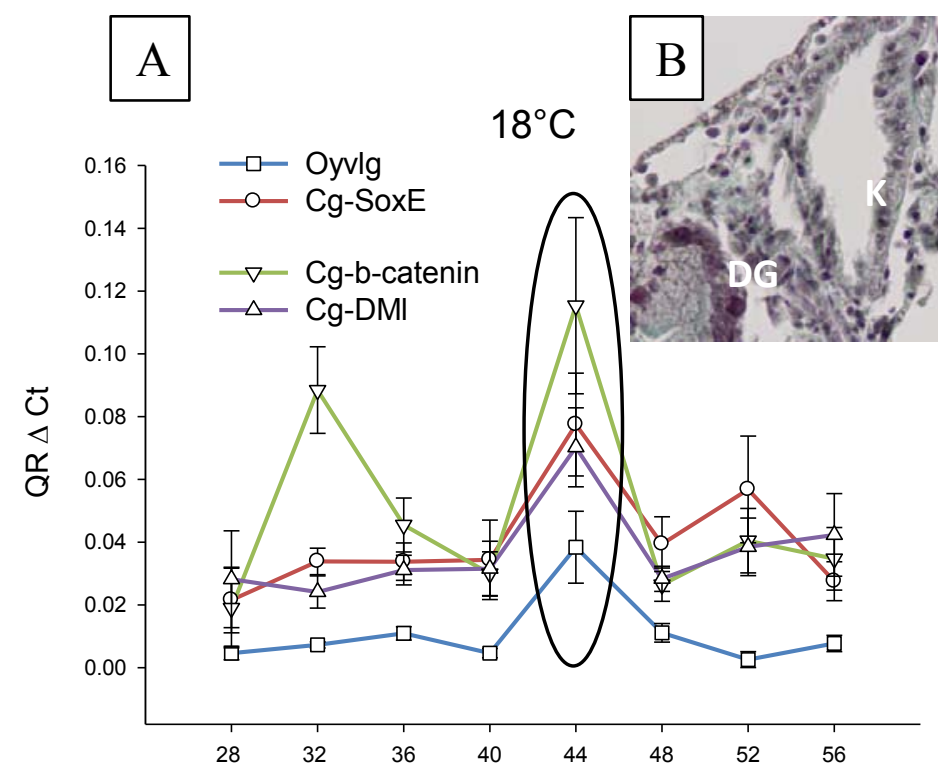

Days post-fertilisation

Figure 2

\section{C}

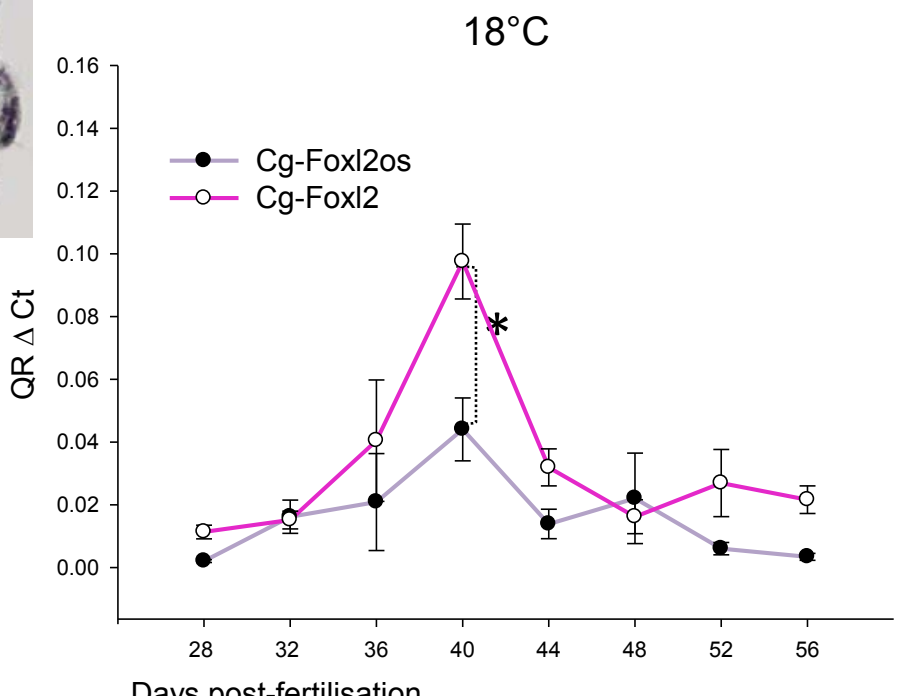

Days post-fertilisation

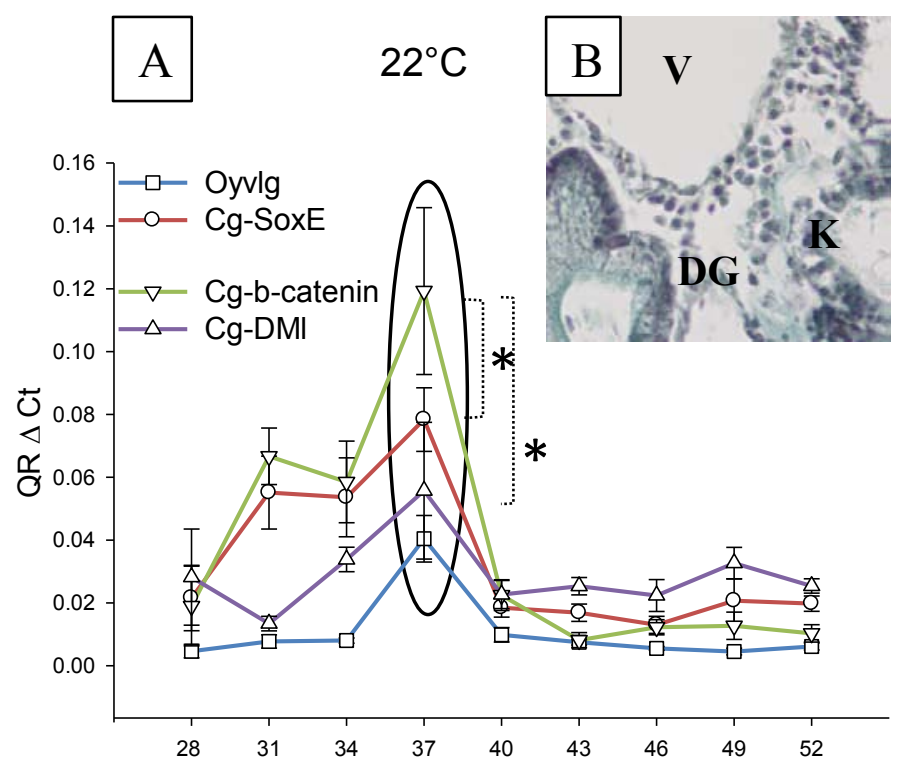

Days post-fertilisation

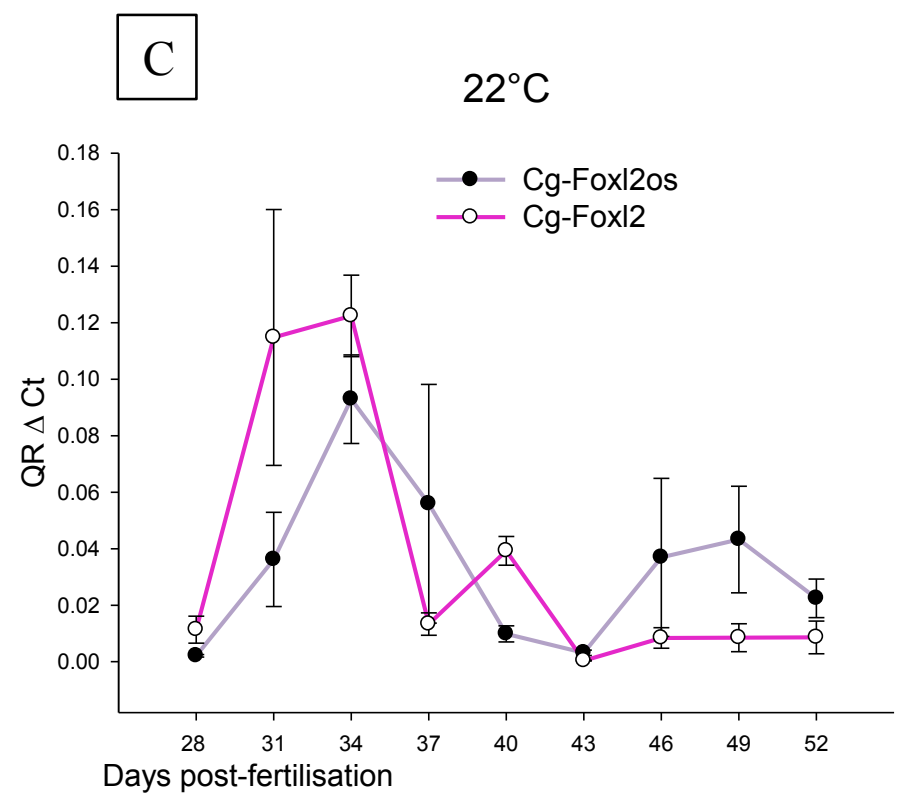

Days post-fertilisation

\section{Figure 3}



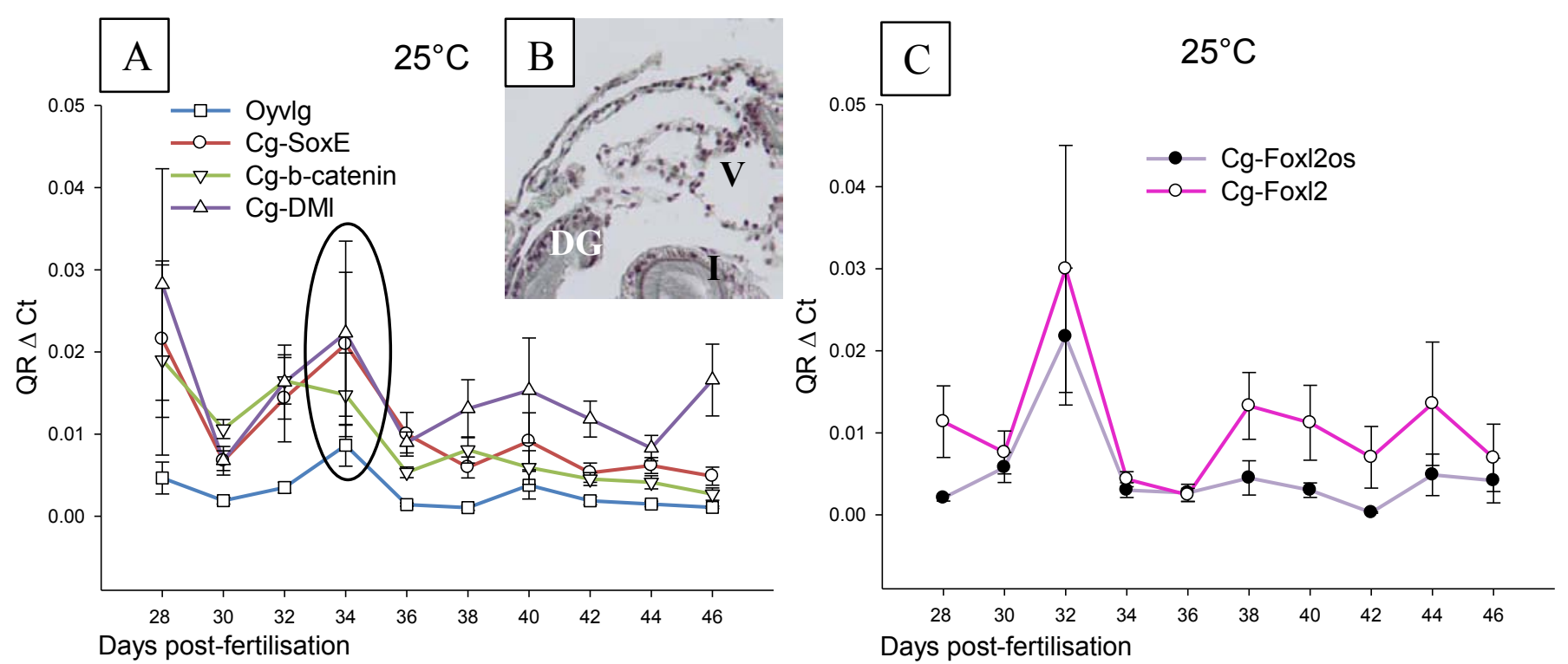

Figure 4
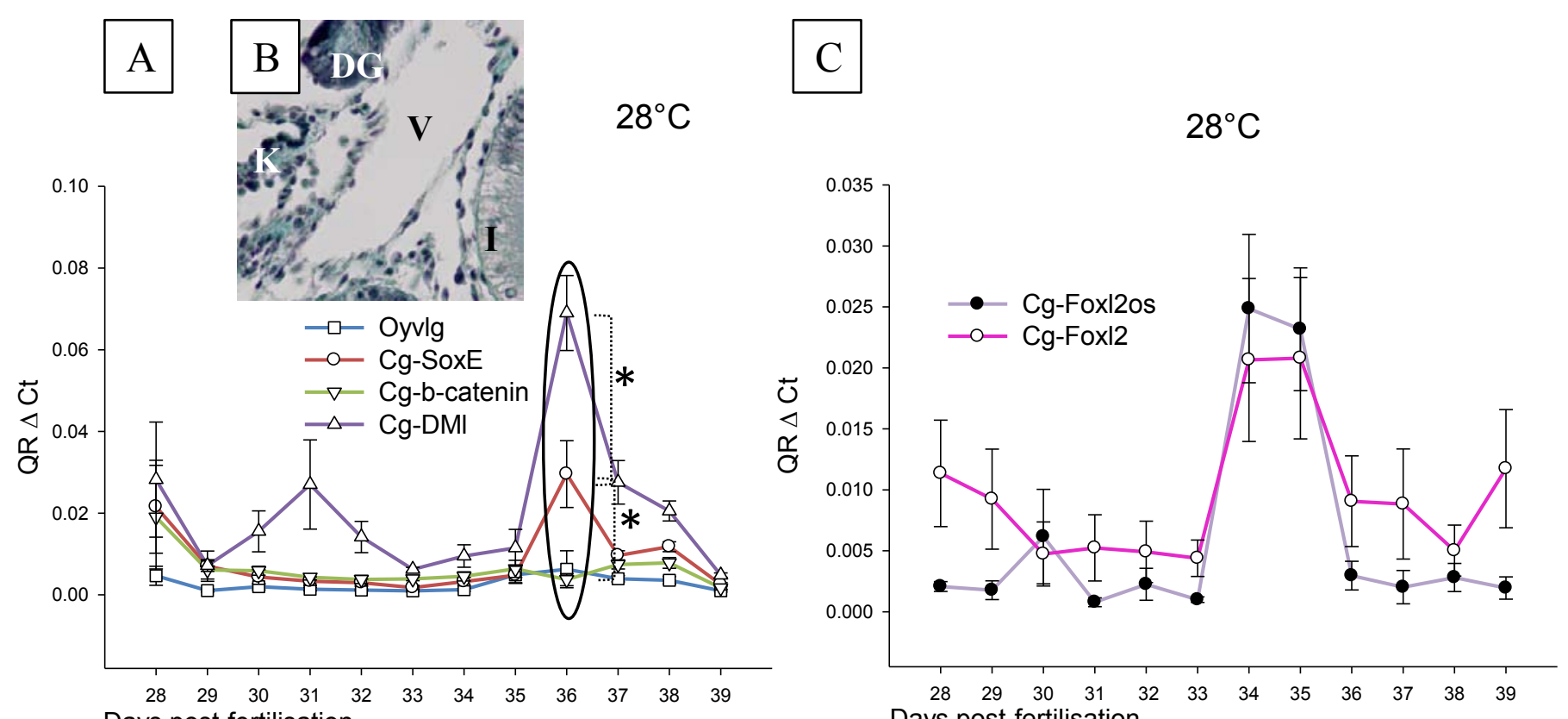

Days post-fertilisation

Days post-fertilisation

\section{Figure 5}

